\title{
Eligibility for and outcome of treatment of latent tuberculosis infection in a cohort of HIV-infected people in Spain
}

\author{
Asuncion Diaz ${ }^{1 *}$, Mercedes Diez ${ }^{2}$, Maria Jose Bleda ${ }^{1}$, Mikel Aldamiz $^{3}$, Miguel Camafort $^{4}$, Xabier Camino $^{5}$, \\ Concepcion Cepeda ${ }^{6}$, Asuncion Costa ${ }^{6}$, Oscar Ferrero ${ }^{7}$, Paloma Geijo $^{8}$, Jose Antonio Iribarren ${ }^{5}$, Santiago Moreno ${ }^{9}$, \\ Maria Elena Moreno ${ }^{9}$, Pablo Labarga ${ }^{10}$, Javier Pinilla ${ }^{10}$, Joseba Portu$^{3}$, Federico Pulido ${ }^{6}$, Carmen Rosa ${ }^{8}$, \\ Juan Miguel Santamaría ${ }^{7}$, Mauricio Telenti ${ }^{11}$, Luis Trapiella ${ }^{11}$, Monica Trastoy ${ }^{12}$, Pompeyo Viciana ${ }^{12}$
}

\begin{abstract}
Background: Previous studies have demonstrated the efficacy of treatment for latent tuberculosis infection (TLTBI) in persons infected with the human immunodeficiency virus, but few studies have investigated the operational aspects of implementing TLTBI in the co-infected population.The study objectives were to describe eligibility for TLTBI as well as treatment prescription, initiation and completion in an HIV-infected Spanish cohort and to investigate factors associated with treatment completion.
\end{abstract}

Methods: Subjects were prospectively identified between 2000 and 2003 at ten HIV hospital-based clinics in Spain. Data were obtained from clinical records. Associations were measured using the odds ratio (OR) and its 95\% confidence interval (95\% Cl).

Results: A total of 1242 subjects were recruited and 846 (68.1\%) were evaluated for TLTBI. Of these, 181 (21.4\%) were eligible for TLTBI either because they were tuberculin skin test (TST) positive (121) or because their TST was negative/unknown but they were known contacts of a TB case or had impaired immunity (60). Of the patients eligible for TLTBI, 122 (67.4\%) initiated TLTBI: 99 (81.1\%) were treated with isoniazid for 6, 9 or 12 months; and 23 (18.9\%) with short-course regimens including rifampin plus isoniazid and/or pyrazinamide. In total, 70 patients (57.4\%) completed treatment, 39 (32.0\%) defaulted, 7 (5.7\%) interrupted treatment due to adverse effects, 2 developed TB, 2 died, and 2 moved away. Treatment completion was associated with having acquired HIV infection through heterosexual sex as compared to intravenous drug use (OR:4.6; 95\% Cl:1.4-14.7) and with having taken rifampin and pyrazinamide for 2 months as compared to isoniazid for 9 months (OR:8.3; 95\% Cl:2.7-24.9).

Conclusions: A minority of HIV-infected patients eligible for TLTBI actually starts and completes a course of treatment. Obstacles to successful implementation of this intervention need to be addressed.

\section{Background}

In Spain, there is an extensive overlap between the epidemiology of human immunodeficiency (HIV) and Mycobacterium tuberculosis (M. tuberculosis) infections [1]. The introduction of highly active antiretroviral treatment (HAART) has led to a reduced incidence of tuberculosis (TB) among HIV positive people, but the risk of

\footnotetext{
* Correspondence: adiaz@isciii.es

'Unidad de Epidemiología del VIH/SIDA, Centro Nacional de Epidemiología, Instituto de Salud Carlos III, Madrid, Spain

Full list of author information is available at the end of the article
}

developing TB remains much higher among this group [2] than among those without HIV infection. Thus, as suggested by studies performed in both high and low prevalence areas [3-5], treatment of latent tuberculosis infection (TLTBI) should be used in combination with HAART to control TB in this population.

The efficacy of TLTBI in people co-infected with HIV and TB has been extensively demonstrated [6,7], but no treatment will have a demonstrable effect on public health if the target population is not reached or if

\section{C) Biomed Central}

(C) 2010 Diaz et al; licensee BioMed Central Ltd. This is an Open Access article distributed under the terms of the Creative Commons Attribution License (http://creativecommons.org/licenses/by/2.0), which permits unrestricted use, distribution, and reproduction in any medium, provided the original work is properly cited. 
treatment compliance is far from optimal, as seems to be the case with TLTBI $[8,9]$.

Although HIV is the main risk factor for developing $\mathrm{TB}$, few studies have investigated the operational aspects of implementing TLTBI in the co-infected population [10], and none has been performed in Spain. For this reason we carried out a 3-year longitudinal study to describe tuberculin skin testing (TST) and the prevalence of M. tuberculosis in HIV-infected people in Spain and to investigate obstacles to successful completion of TLTBI in the co-infected population.

A cohort of 1242 HIV-infected subjects was identified during the study period, of whom 84 had past TB, 23 had current TB, and 87 had already been treated for LTBI at study entry. Thus, only 1048 persons were eligible for TST, of whom 853 (81.4\%) underwent testing. The reasons for not undergoing TST were: test not prescribed by the physician (185 cases), patient's refusal (7 cases), and unknown (3 cases). A detailed account of reasons for non-prescription of TST and of M. tuberculosis prevalence in this cohort has already been published $[11,12]$.

The objective of this paper is to describe eligibility for TLTBI, treatment prescription, initiation and completion in HIV-infected subjects in Spain, and factors associated with treatment completion. Since our aim was to assess "routine clinical practice", no attempt was made to modify it in any way.

\section{Methods}

A cohort of HIV-infected people not previously followed at an HIV clinic was prospectively identified between March 2000 and February 2003 at 10 Spanish hospitalbased HIV clinics scattered across a wide geographical area. In Spain, HIV care is always hospital based, and antiretroviral treatment is not available outside this setting.

Subjects were eligible for the study if 1) this was their first visit to an HIV specialist, or 2) this was not the first time an HIV specialist had examined them, but they had not attended an HIV clinic in the preceding 2 years. To avoid the inadvertent inclusion of people who had been followed up in HIV clinics not included in the study, people taking antiretroviral drugs or notified as AIDS cases before study entry were excluded. A more detailed description of the cohort can be found elsewhere [12].

While guidelines for TB prevention in HIV-infected people in Spain have been issued [13], the treating physicians, in accordance with their routine clinical practice, made their own decisions about treatment eligibility, regimens chosen for TLTBI and the number of followup visits.
At study entry a physical examination was performed by the visiting physician. TST was performed in accordance with Spanish guidelines for HIV-positive people [14].

All subjects without signs or symptoms of disease and who had a positive Mantoux test at study entry or a documented positive TST in the past were classified as having latent tuberculosis infection (LTBI).

In accordance with Spanish guidelines [13] a person was considered to be a candidate for TLTBI if he/she did not have past/current TB and: a) was TST $(+)$ and had not taken TLTBI previously; b) was TST (-) but was a known contact of a TB patient; or c) was TST (-) but had a CD4 count of less than 500 cells/ $\mu \mathrm{L}$, anergy was suspected and the treating physician considered that TLTBI was necessary.

Treatment outcome was classified in the following mutually exclusive categories: a) treatment completed: a person who, in the clinician's judgment, has completed treatment; b) treatment interruption due to adverse effects: a person who, on the physician's advice, interrupted treatment due to adverse effects; c) treatment default: a person who interrupted treatment for reasons other than adverse effects; d) development of TB: a person who developed TB while in TLTBI; e) moved away: a person who changed residence while in TLTBI and whose outcome was unknown; f) death: a person who died while in TLTBI independently of the cause.

By consensus among the participating clinicians, a patient was considered to be adherent if he/she had taken at least $80 \%$ of the total pills prescribed; however, treatment adherence was assessed only in accordance with the treating physician's judgment.

Socio-demographic, epidemiological and clinical information and data on follow-up visits and treatment outcome were obtained from the clinical records.

Characteristics of subjects who were prescribed TLTBI, those who initiated treatment, and those who completed it were described. The chi-squared or Fisher's exact tests were used to evaluate the association between qualitative variables. The odds ratio and its 95\% confidence interval (OR, 95\% CI) were used to measure the association between different variables and completion of TLTBI. The multivariate analysis was performed using logistic regression following Hosmer and Lemeshow model-building strategies and methods [15], taking into consideration that the sample size was not very large [16]. Data analysis was performed using the STATA program (Version 10.0).

The study was performed following all the requirements of the Spanish legislation on data protection in effect at the time, and was reviewed by the corresponding boards of the institutions involved. 


\section{Results}

a) Eligibility for TLTBI and treatment initiation

Of the 853 HIV-infected subjects who underwent TST, $846(99.2 \%)$ returned for the reading, and 121 (14.3\% of the tests read) were TST(+); none of them had signs or symptoms of TB disease and were, thus, eligible for TLTBI. Additionally, the treating physicians considered that 57 TST(-) and three TST unknown patients were also eligible for TLTB (Figure 1). Thus, of the $856 \mathrm{HIV-}$ positive people evaluated for TLTBI, 181 (21.1\%) were found to be eligible. However, only 122 of the latter (67.4\%) finally initiated treatment (Figure 1).

Reasons for not initiating treatment were: a) physicians questioned patients' compliance due to their social situation ( $\mathrm{n}=20)$; b) medical contraindication $(\mathrm{n}=19)$; c) patient's refusal $(\mathrm{n}=17)$; and $\mathrm{d})$ unknown causes $(\mathrm{n}$ = 3). All patients who rejected TLTBI were Spaniards: 13 were intravenous drug users (IDU) and were infected with Hepatitis $\mathrm{C}$ virus (HCV), 9 were unemployed, and 8 had poor or no education. Characteristics of subjects eligible for treatment of LTBI and those who actually initiated it are presented in table 1.
The regimens prescribed for TLTBI were: a) isoniazid 6 months $(6 \mathrm{H})$ : 51 patients $(41.8 \%)$; b) isoniazid 9 months (9H): 26 (21.3\%); c) isoniazid 12 months $(12 \mathrm{H}): 22(18.0 \%) ;$ d) rifampin plus pyrazinamide 2 months (2RZ): 17 (13.9\%); e) rifampin plus isoniazid 3 months (3RH): 5 (4.1\%); and f) rifampin plus isoniazid plus pyrazinamide 3 months (3RHZ): 1 patient $(0.8 \%)$.

\section{b) Treatment outcomes}

Of the 122 patients who initiated TLTBI, 70 (57.4\%) completed treatment, 39 (32.0\%) defaulted, 7 (5.7\%) interrupted treatment because of adverse effects, 2 (1.6\%) developed TB, 2 (1.6\%) died, and 2 (1.6\%) changed residence and the final result was unknown.

Default rates were greater among IDUs than among men who have sex with men (MSM) and heterosexuals: $44.0 \%, 23.5 \%$ and $18.1 \%$ respectively ( $\mathrm{p}=0.02)$.

Regarding treatment regimens, default rates for the long-term regimens $12 \mathrm{H}, 6 \mathrm{H}$, or $9 \mathrm{H}$ were $40.9 \%$, $39.2 \%$ and $30.8 \%$, respectively. The corresponding figures for the short-term regimens $2 \mathrm{RZ}, 3 \mathrm{RH}$ and $3 \mathrm{RHZ}$ were $5.9 \%, 20 \%$ and $0 \%$.

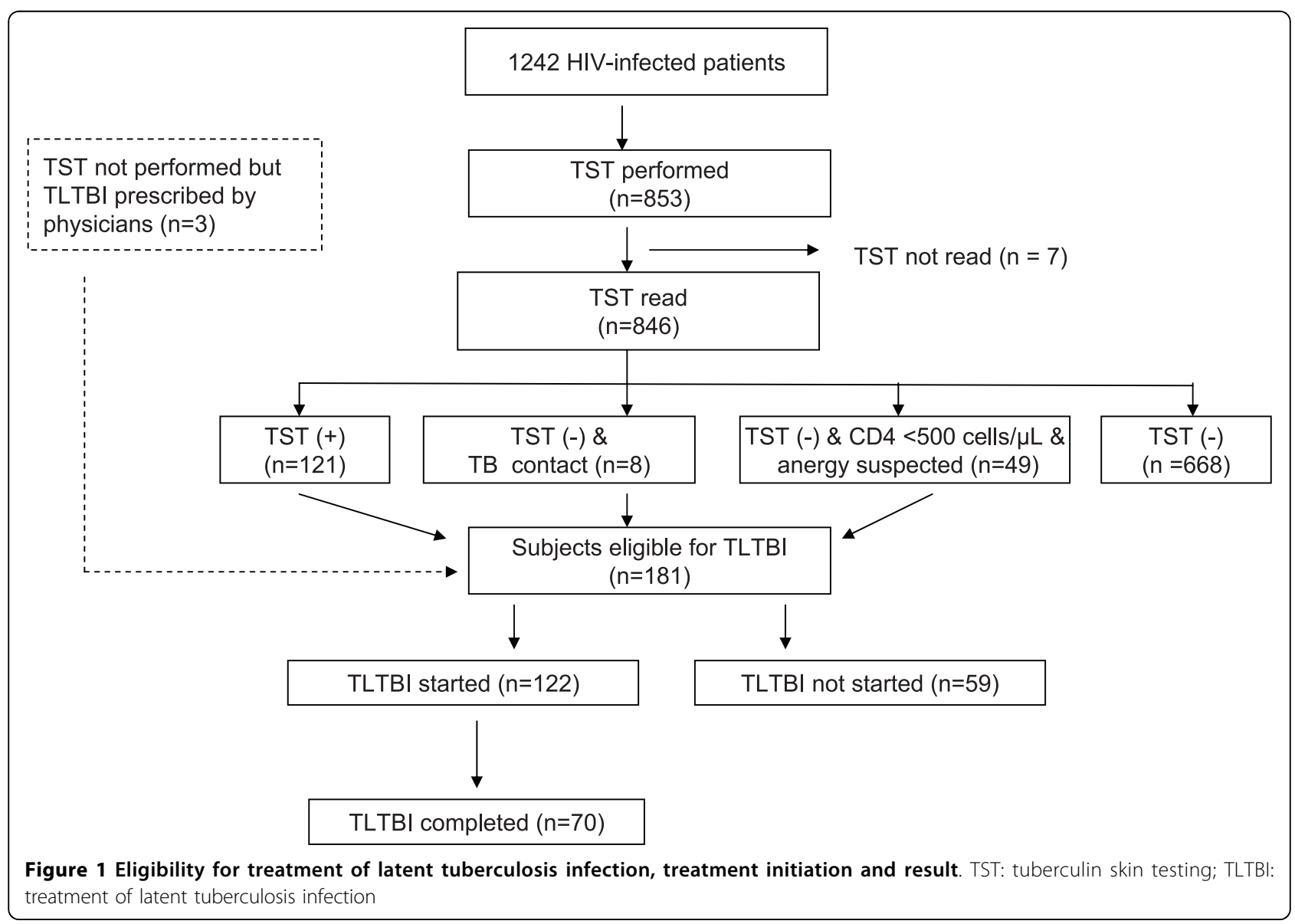


Table 1 Characteristics of study subjects according to treatment of latent tuberculosis infection

\begin{tabular}{|c|c|c|c|c|c|c|}
\hline \multirow[t]{2}{*}{ Variables } & \multicolumn{2}{|c|}{ Eligible for TLTBI } & \multicolumn{2}{|c|}{$\begin{array}{c}\text { Initiated } \\
\text { TLTBI }\end{array}$} & \multicolumn{2}{|c|}{ Completed TLTBI } \\
\hline & $\mathrm{N}$ & (\%) & $\mathrm{n}$ & (\%) & $\mathrm{n}$ & (\%) \\
\hline \multicolumn{7}{|l|}{ Sex } \\
\hline Male & 141 & $(77.9)$ & 92 & (75.4) & 52 & (74.3) \\
\hline Female & 40 & $(22.1)$ & 30 & (24.6) & 18 & $(25.7)$ \\
\hline \multicolumn{7}{|l|}{ Age group (years) } \\
\hline$\leq 30$ & 48 & $(26.5)$ & 39 & (32.0) & 20 & (28.6) \\
\hline $31-35$ & 53 & $(29.3)$ & 33 & $(27.0)$ & 15 & $(21.4)$ \\
\hline $36-40$ & 40 & $(22.1)$ & 22 & (18.0) & 13 & (18.6) \\
\hline$\geq 41$ & 40 & $(22.1)$ & 28 & $(23.0)$ & 22 & (31.4) \\
\hline \multicolumn{7}{|l|}{ Country of origin } \\
\hline Spain & 154 & $(85.1)$ & 101 & $(82.8)$ & 58 & $(82.9)$ \\
\hline Other & 27 & $(14.9)$ & 21 & $(17.2)$ & 12 & $(17.1)$ \\
\hline \multicolumn{7}{|l|}{ Educational level } \\
\hline None/incomplete primary education & 24 & $(13.3)$ & 14 & $(11.5)$ & 6 & $(8.6)$ \\
\hline Primary education completed & 80 & $(44.2)$ & 54 & $(44.3)$ & 33 & $(47.1)$ \\
\hline Secondary/university education completed & 48 & $(26.5)$ & 34 & $(27.9)$ & 18 & $(25.7)$ \\
\hline Unknown & 29 & $(16.0)$ & 20 & $(16.3)$ & 13 & $(18.6)$ \\
\hline \multicolumn{7}{|l|}{ Employment status } \\
\hline Employed & 73 & $(40.3)$ & 49 & $(40.2)$ & 33 & $(47.1)$ \\
\hline Unemployed & 83 & $(45.9)$ & 56 & $(45.9)$ & 27 & (38.6) \\
\hline Other & 20 & $(11.0)$ & 13 & $(10.6)$ & 7 & $(10.0)$ \\
\hline Unknown & 5 & $(2.8)$ & 4 & (3.3) & 3 & (4.3) \\
\hline \multicolumn{7}{|l|}{ HIV transmission route } \\
\hline IDU & 101 & $(55.8)$ & 59 & $(48.4)$ & 28 & $(40.0)$ \\
\hline MSM & 22 & $(12.2)$ & 17 & (13.9) & 7 & $(10.0)$ \\
\hline Heterosexual sex & 53 & $(29.3)$ & 44 & $(36.1)$ & 34 & $(48.6)$ \\
\hline Other/unknown & 5 & $(2.8)$ & 2 & $(1.6)$ & 1 & $(1.4)$ \\
\hline \multicolumn{7}{|l|}{ Viral load (copies) } \\
\hline$<50$ & 17 & $(9.4)$ & 8 & (6.6) & 6 & (8.6) \\
\hline $50-9,999$ & 57 & $(31.5)$ & 43 & $(35.2)$ & 29 & $(41.4)$ \\
\hline $10,000-54,999$ & 45 & $(24.9)$ & 30 & (24.6) & 15 & $(21.4)$ \\
\hline$\geq 55,000$ & 58 & $(32.0)$ & 39 & (32.0) & 19 & $(27.1)$ \\
\hline Unknown & 4 & $(2.2)$ & 2 & $(1.6)$ & 1 & $(1.4)$ \\
\hline \multicolumn{7}{|l|}{ CD4 (cells/uL) } \\
\hline$<100$ & 22 & $(12.2)$ & 11 & $(9.0)$ & 5 & $(7.1)$ \\
\hline 100-199 & 24 & (13.3) & 16 & (13.1) & 10 & (14.3) \\
\hline $200-499$ & 75 & $(41.4)$ & 52 & (42.6) & 28 & $(40.0)$ \\
\hline$\geq 500$ & 60 & (33.1) & 43 & $(35.2)$ & 27 & (38.6) \\
\hline \multicolumn{7}{|l|}{ Hepatitis B carriers } \\
\hline Yes & 14 & $(7.7)$ & 9 & $(7.4)$ & 3 & (4.3) \\
\hline No & 163 & $(90.1)$ & 112 & (91.8) & 67 & $(95.7)$ \\
\hline Unknown & 4 & $(2.2)$ & 1 & $(0.8)$ & 0 & $(0.0)$ \\
\hline \multicolumn{7}{|l|}{ Hepatitis C virus antibodies } \\
\hline Yes & 107 & $(59.1)$ & 62 & $(50.8)$ & 31 & $(44.3)$ \\
\hline No & 69 & $(38.1)$ & 57 & $(46.7)$ & 38 & $(54.3)$ \\
\hline Unknown & 5 & $(2.8)$ & 3 & $(2.5)$ & 1 & $(1.4)$ \\
\hline$\overline{T O T A L}$ & 181 & $(100.0)$ & 122 & $(100.0)$ & 70 & $(100.0)$ \\
\hline
\end{tabular}

TLTBI: treatment of latent tuberculosis infection; IDU: Intravenous drug user; MSM: Men who have sex with men 
Table 2 Number of defaulters, by month when treatment of latent tuberculosis infection was abandoned and type of regimen

\begin{tabular}{|c|c|c|c|c|c|c|c|c|c|c|c|c|c|c|c|}
\hline \multirow[t]{2}{*}{ Type of TLTBI } & \multirow[t]{2}{*}{ No of people starting TLTBI } & \multicolumn{13}{|c|}{ Month Defaulting } & \multirow{2}{*}{$\begin{array}{c}\text { Early } \\
\text { defaulters/Total defaulters } \\
(\%)\end{array}$} \\
\hline & & $0^{*}$ & 1 & 2 & 3 & 4 & 5 & 6 & 7 & 8 & 9 & 10 & 11 & 12 & \\
\hline $6 \mathrm{H}$ & 51 & 6 & 5 & 5 & & 2 & 2 & & & & & & & & $\begin{array}{c}6 / 20 \\
(30.0 \%)\end{array}$ \\
\hline $9 \mathrm{H}$ & 26 & 3 & & 2 & & 2 & & & & 1 & & & & & $\begin{array}{c}3 / 8 \\
(37.5 \%)\end{array}$ \\
\hline $12 \mathrm{H}$ & 22 & 6 & 1 & 1 & & & & & & & 1 & & & & $\begin{array}{c}6 / 9 \\
(66.6 \%)\end{array}$ \\
\hline $2 \mathrm{RZ}$ & 17 & 1 & & & & & & & & & & & & & $1 / 1$ \\
\hline $3 \mathrm{RH}$ & 5 & & 1 & & & & & & & & & & & & $0 / 1$ \\
\hline Total & & 16 & 7 & 8 & & 4 & 2 & & & 1 & 1 & & & & 39 \\
\hline
\end{tabular}

TLTBI: Treatment of latent tuberculosis infection; H: isoniazid; R: rifampin; Z: pyrazinamide

* Patient did not return after the visit when TLTBI was prescribed

Out of the 39 defaulters, 23 (59\%) abandoned treatment in the first month, 16 of whom did not return after the visit when TLTBI was prescribed (Table 2).

Out of the seven patients with adverse reactions, five developed hepatotoxicity within the first 2 months of treatment (one for each regime except 3RHZ), one developed exanthema in the fourth month of a $9 \mathrm{H}$ regimen, and the last one developed gastric intolerance in the tenth month of a $12 \mathrm{H}$ regimen.

The two subjects who developed TB were MSM under age 35 whose infection was detected within the first month after treatment initiation.

Two patients died while in treatment. One was an IDU co-infected with HCV who died in the first month of TLTBI and the other was a MSM with a very low CD4 count who died during the second month. Neither of these deaths was related to TLTBI.

\section{Factors associated with treatment completion}

The 70 patients completing treatment had a mean age of 37.1 (SD:8.8) years, and were mostly men (74.3\%) and Spaniards (82.9\%). Almost $60.0 \%$ had acquired HIV infection through sex. Regarding their initial clinical evaluation, $50.0 \%$ had less than 10,000 viral copies, and almost 79\% had more than 200 CD4 (Table 1).

Treatment completion was significantly greater among people infected with HIV through heterosexual sex than among IDU or MSM $(77.3 \%$ vs. $47.5 \%$ and $41.2 \%$ respectively) $(\mathrm{p}=0.01)$.

The only patient treated with $3 \mathrm{RHZ}$, as well as three out of the five treated with $3 \mathrm{RH}$ finished the treatment. Among people treated with $2 \mathrm{RZ}$ the completion rate was $88.2 \%$, and among those who had taken $9 \mathrm{H}, 6 \mathrm{H}$ or $12 \mathrm{H}$, treatment completion rates were $53.8 \%, 56.9 \%$ and $36.4 \%$ respectively.
The multivariate analysis to identify factors associated with treatment completion excluded subjects who died while in TLTBI, those who developed TB and those who left treatment because of adverse effects, since these persons could not complete treatment. Thus, only the 111 patients who had completed treatment, defaulted or moved away were included in this analysis. Treatment completion was greater among patients acquiring HIV through heterosexual sex as compared to IDUs (OR:4.6; 95\% CI: 1.4-14.7) and those treated with $2 \mathrm{RZ}$ as compared to those treated with $9 \mathrm{H}$ (OR:8.3; 95\% CI:2.7-24.9) (Table 3).

\section{Discussion}

This is the first study performed in Spain that describes eligibility, initiation and outcome of TLTBI in routine clinical practice among HIV-infected subjects. In total, 1242 people entered the study. Of these, 181 were eligible for treatment, 122 initiated it, and only $70 \mathrm{com}$ pleted treatment. Thus, only $38.7 \%$ of people eligible for TLTBI, actually finished the treatment. These findings suggest that there are many obstacles to completing TLTBI in the HIV-infected population.

Around one in five persons eligible for TLTBI did not initiate it, either because the treatment was not prescribed or because the patient refused to take it. In both instances the patients' social context seemed to be a major determinant. Thus, some physicians did not prescribe TLTBI because they expected the patient's social situation to make treatment compliance difficult; similarly, most of the patients refusing treatment had unfavorable social indicators.

Almost $11 \%$ of those potentially eligible for TLTBI did not initiate it because of medical contraindications. This figure is lower than the $17 \%$ found in a similar study 
Table 3 Factors associated with completed TLTBI. Univariate and multivariate analyses $(n=111)$

\begin{tabular}{|c|c|c|c|c|c|c|}
\hline \multirow[b]{2}{*}{ Variables } & \multicolumn{3}{|c|}{$\begin{array}{l}\text { Univariate } \\
\text { Analysis }\end{array}$} & \multicolumn{3}{|c|}{$\begin{array}{l}\text { Multivariate } \\
\text { Analysis }\end{array}$} \\
\hline & $\begin{array}{c}\text { Crude } \\
\text { OR }\end{array}$ & $(95 \% \mathrm{Cl})$ & $p$ value & Adjusted OR & $(95 \% \mathrm{Cl})$ & $P$ value \\
\hline \multicolumn{7}{|l|}{ Sex } \\
\hline Female & 1 & & & 1 & & \\
\hline Male & 1.2 & $(0.9-1.6)$ & 0.244 & 2.1 & $(0.9-4.9)$ & 0.081 \\
\hline \multicolumn{7}{|l|}{$\overline{\text { Age group (years) }}$} \\
\hline $19-29$ & 1 & & & 1 & & \\
\hline $30-34$ & 1.1 & $(0.4-2.9)$ & 0.808 & 1.2 & $(0.3-5.1)$ & 0.789 \\
\hline $35-38$ & 1.2 & $(0.4-3.5)$ & 0.702 & 1.4 & $0.4-4.5)$ & 0.599 \\
\hline $39-61$ & 3.6 & $(1.1-11.9)$ & 0.035 & 2.9 & $(0.6-13.1)$ & 0.173 \\
\hline \multicolumn{7}{|l|}{ HIV transmission route } \\
\hline IDU & 1 & & & 1 & & \\
\hline MSM & 1.7 & $(0.2-12.3)$ & 0.606 & 2.0 & $(0.3-12.2)$ & 0.458 \\
\hline Heterosexual & 3.6 & $(1.3-9.8)$ & 0.010 & 4.6 & $(1.4-14.7)$ & 0.010 \\
\hline Other/Unknown & 1.0 & $(0.1-13.7)$ & 0.979 & 1.3 & $(0.2-7.6)$ & 0.793 \\
\hline \multicolumn{7}{|l|}{ Type of TLTBI } \\
\hline $9 \mathrm{H}$ & 1 & & & 1 & & \\
\hline $6 \mathrm{H}$ & 0.9 & $(0.3-2.9)$ & 0.861 & 0.6 & $(0.2-2.2)$ & 0.505 \\
\hline $12 \mathrm{H}$ & 0.6 & $(1.1-2.2)$ & 0.423 & 0.6 & $(0.2-1.9)$ & 0.382 \\
\hline $2 R Z$ & 9.6 & $(1.1-81.4)$ & 0.037 & 8.3 & $(2.7-24.9)$ & 0.000 \\
\hline $3 \mathrm{RH}$ & 1.9 & $(0.2-21.1)$ & 0.591 & 1.7 & $(0.1-24.2)$ & 0.702 \\
\hline
\end{tabular}

OR: Odds ratio; Cl: confidence interval

TLTBI: Treatment of latent tuberculosis infection; IDU: Intravenous drug user; MSM: Men who have sex with men; H: isoniazid; R: rifampin; Z: pyrazinamide Multivariate model adjusted by hospital

performed in Italy [10], although in both studies hepatitis $\mathrm{C}$ was the most common contraindication.

In this study, $6 \%$ of people who began TLTBI had to interrupt it due to adverse effects. This proportion was higher than the $3.7 \%$ found in an American study where a $2 \mathrm{RZ}$ regimen was used [17], and lower that the $10 \%$ found in the aforementioned Italian study, where $6 \mathrm{H} / 12 \mathrm{H}$ regimens were used [10]. Results from other Spanish studies-two clinical trials in HIVinfected people and an observational study in non-HIV infected people [18-20]-showed higher rates of adverse effects: $15 \%, 9.7 \%$ and $12.4 \%$, respectively. These differences may be due to different regimens being used or to closer patient follow-up.

The proportion of defaulters in our study was higher than the $22 \%$ and $27 \%$ found in the Spanish clinical trials $[18,19]$. Defaulter rates in other non-Spanish observational studies performed in HIV-infected patients $[10,17,21]$ vary considerably, ranging from $8 \%$ to $42 \%$, depending on the type of regimen chosen and whether or not directly observed treatment (DOT) was used.

Defaulting was common with long-term regimens, but it is interesting to note that most patients abandoned early in the course of treatment, and more than $40 \%$ of the defaulters failed to return for the first follow-up visit. This finding, common to other studies $[17,22]$, may indicate that patients do not clearly understand the benefits of TLTBI.

The treatment completion rate, $57.4 \%$, is comparable to those found in the Spanish clinical trials, $61 \%$ and $63.3 \%$ respectively $[18,19]$. As compared with findings from international studies, the completion rate was similar to the $61 \%$ found in an observational study carried out in United States with a $12 \mathrm{H}$ regimen [17], but worse than those in two other studies in Italy and Brazil, which reported completion rates of $72.5 \%$ and 76.1 , using 6-12 $\mathrm{H}$ and $6 \mathrm{H}$ regimes, respectively $[10,3]$.

The finding that treatment completion was better in patients who had acquired HIV through heterosexual sex than among IDUs was not at all surprising, since Spanish IDUs have also been found to have poor compliance with antiretroviral treatment [23]. In fact, what is surprising is that almost $50 \%$ of all IDUs initiating TLTBI completed it, a figure similar to what has been found in studies where DOT was used $[24,25]$. This "good" result is explained by the positive selection that had taken place among the IDUs during the clinical process previous to treatment prescription: IDUs were over-represented among subjects who did not undergo TST [11] and constituted the majority of eligible patients for whom TLTBI was not prescribed (82.6\%). 
Treatment completion was significantly better with the $2 \mathrm{RZ}$ regimen than with the $9 \mathrm{H}$ regimen. This result is consistent with those of some clinical trials where adherence to this regimen was between $73.4 \%$ and $80.0 \%$ [26-28]. In an observational study with this regimen where DOT was utilized, the completion rate reached 93\% [17]. Unfortunately, this regimen has been associated with severe liver injury, mostly in HIV-negative but also in HIV-infected people, and some institutions have withdrawn it from the list of recommended regimens for the treatment of LTBI [29]. We found no differences in the occurrence of adverse events with the different regimens, but numbers were small.

Our study has some limitations. The small number of study participants prevented an in depth analysis of factors associated with treatment prescription and treatment initiation. Such analyses would have provided a better understanding of physician-and patient-related variables associated with treatment prescription or treatment initiation. Furthermore, small sample sizes could have sometimes resulted in less precise estimates.

\section{Conclusions}

This study shows that, despite the high prevalence of M. tuberculosis and TB disease in the HIV-infected population in Spain [12] and the potential benefit of treating LTBI [30], the outcome of TLTBI in routine clinical practice is far from desirable: less than half of the patients eligible for treatment actually take it. Reasons for this situation are diverse, but social or structural causes seem to play a far greater role than medical reasons.

The study results have some public health implications: a) adequate enablers should be used to facilitate TLTBI among IDUs; b) health staff should try to help patients understand the importance of TLTBI; and c) further research is needed to fully understand patient and physician behavioral factors influencing initiation and completion of TLTBI.

\section{Acknowledgements \\ This work was funded by a grant (3041/99) from the Foundation for AIDS Research and Prevention in Spain (Fundación para la Investigación y la Prevención del SIDA en España-FIPSE). The authors are grateful to Kathy Fitch for English review.}

\footnotetext{
Author details

${ }^{1}$ Unidad de Epidemiología del VIH/SIDA, Centro Nacional de Epidemiología, Instituto de Salud Carlos III, Madrid, Spain. ${ }^{2}$ Secretaria del Plan Nacional sobre el sida, Ministerio de Sanidad y Política Social, Madrid, Spain. ${ }^{3}$ Servicio Medicina Interna, Hospital Txagorritxu,Vitoria, Spain. ${ }^{4}$ Servicio Medicina Interna, Hospital Mora d'Ebre, Instituto de Investigación Sanitaria "Pere Virgili", Universidad "Rovira i Virgili", Mora d'Ebre, Spain. ${ }^{5}$ Servicio de Enfermedades Infecciosas, Hospital Ntra Sra de Aranzazu, San Sebastián, Spain. ${ }^{6}$ Unidad VIH, Hospital Doce de Octubre, Madrid, Spain. ${ }^{7}$ Servicio Enfermedades Infecciosas, Hospital de Basurto, Bilbao, Spain. ${ }^{8}$ Servicio Medicina Interna, Hospital Virgen de la Luz, Cuenca, Spain. ${ }^{9}$ Servicio de
}

Enfermedades Infeccciosas, Hospital Ramón y Cajal, Madrid, Spain. ${ }^{10}$ Servicio de Medicina Interna, Hospital San Millán, Logroño, Spain. ${ }^{11}$ Unidad de Enfermedades Infecciosas, Hospital Universitario Central de Asturias, Oviedo, Spain. ${ }^{12}$ Servicio Enfermedades Infecciosas, Hospital Virgen del Rocío, Sevilla, Spain.

\section{Authors' contributions}

AD worked on data collection and management, carried out the epidemiological analysis, prepared the figure and most of the tables, wrote the first version of the manuscript and contributed to all successive versions. MD was the main study researcher. She had the original idea, developed the study protocol, supervised field work and data collection, and wrote the statistical analysis plan and the final version of the manuscript. MJB performed data collection and management, quality control and statistical analysis, and reviewed all the manuscript drafts. MA, MC, XC, CC, AC, OF, PG, JAI, SM, MEM, PL, JP, JP, FP, CR, JMS, MT, LT,MT and PV were the physicians responsible for patient recruitment and follow-up in the participating hospitals. They all participated in development of the study protocol, collection of epidemiological and clinical data, and critical review of all versions of the manuscript.

\section{Competing interests}

The authors declare that they have no competing interests.

Received: 17 February 2010 Accepted: 14 September 2010 Published: 14 September 2010

\section{References}

1. Diez M, Huerta C, Moreno T, Caloto T, Guerra D, Pozo F, Alcaide J, Castells C, Cardenal Jl, Domínguez A, Gayoso P, Gutiérrez G, López MJ, Muñoz F, Navarro C, Picó M, Quirós JR, Robles F, Sánchez JM, Vanaclocha H, Vega T, Multicentre Project for Tuberculosis Research (MPTR) Study Group: Tuberculosis in Spain: epidemiological pattern and clinical practice. Int J Tuberc Lung Dis 2002, 6:295-300.

2. Muga R, Ferreros I, Langohr K, de Olalla PG, Del Romero J, Quintana M, Alastrue I, Belda J, Tor J, Pérez-Hoyos S, Del Amo J, Spanish Multicenter Study Group of Seroconverters (GEMES): Changes in the incidence of tuberculosis in a cohort of HIV-seroconverters before and after the introduction of HAART. AIDS 2007, 21:2521-2527.

3. Golub JE, Saraceni V, Cavalcante SC, Pacheco AG, Moulton LH, King BS, Efron A, Moore RD, Chaisson RE, Durovni B: The impact of antiretroviral therapy and isoniazid preventive therapy on tuberculosis incidence in HIV-infected patients in Rio de Janeiro, Brazil. AIDS 2007, 21:1441-1448.

4. Girardi E, Sabin CA, d'Arminio Monforte A, Hogg B, Phillips AN, Gill MJ, Dabis F, Reiss P, Kirk O, Bernasconi E, Grabar S, Justice A, Staszewski S, Fätkenheuer G, Sterne JA, Antiretroviral Therapy Cohort Collaboration: Incidence of tuberculosis among HIV-infected patients receiving highly active antiretroviral therapy in Europe and North America. Clin Infect Dis 2005, 41:1772-1782.

5. Elzi L, Schlegel M, Weber R, Hirschel B, Cavassini M, Schmid P, Bernasconi E, Rickenbach M, Furrer H, Swiss HIV Cohort Study: Reducing tuberculosis incidence by tuberculin skin testing, preventive treatment, and antiretroviral therapy in an area of low tuberculosis transmission. Clin Infect Dis 2007, 44:94-102.

6. Woldehanna S, Volmink J: Treatment of latent tuberculosis infection in HIV infected persons. Cochrane Database Syst Rev 2004, 1:CD000171.

7. Churchyard GJ, Scano F, Grant AD, Chaisson RE: Tuberculosis preventive therapy in the era of HIV infection: overview and research priorities. $J$ Infect Dis 2007, 196(Suppl 1):S52-62.

8. Munro SA, Lewin SA, Smith HJ, Engel ME, Fretheim A, Volmink J: Patient adherence to tuberculosis treatment: a systematic review of qualitative research. PLoS Med 2007, 24:e238.

9. Hirsch-Moverman Y, Daftary A, Franks J, Colson PW: Adherence to treatment for latent tuberculosis infection: systematic review of studies in the US and Canada. Int J Tuberc Lung Dis 2008, 12:1235-1254.

10. Antonucci G, Girardi E, Raviglione M, Vanacore P, Angarano G, Chirianni A, Pagano G, Suter F, Lauria FN, Ippolito G: Guidelines of tuberculosis preventive therapy for HIV-infected persons: a prospective, multicentre study. GISTA (Gruppo Italiano di Studio Tubercolosi e AIDS). Eur Respir J 2001, 18:369-375. 
11. Diaz A, Diez M, Bleda MJ, Aldamiz M, Camafort M, Camino X, Cepeda C, Costa A, Ferrero O, Geijo P, Iribarren JA, Moreno S, Moreno ME, Labarga P, Pinilla J, Portu J, Pulido F, Rosa C, Santamaría JM, Telenti M, Trapiella L, Trastoy M, Viciana P: Factores asociados a la no realización de la prueba de la tuberculina en una cohorte de pacientes VIH positivos [Factors related to non-prescription of tuberculin skin testing in a cohort of HIVinfected people]. Enferm Infecc Microbiol Clin 2010, 28:215-21.

12. Diez M, Diaz A, Bleda MJ, Aldamiz M, Camafort M, Camino X, Cepeda C, Costa A, Ferrero O, Geijo P, Iribarren JA, Moreno S, Moreno ME, Labarga P, Pinilla J, Portu J, Pulido F, Rosa C, Santamaria JM, Telenti M, Trapiella L, Trastoy M, Viciana P: Prevalence of $M$. tuberculosis infection and tuberculosis disease among HIV-infected people in Spain. Int J Tuberc Lung Dis 2007, 11:1196-1202.

13. Berenguer J, Laguna F, López-Aldeguer J, Moreno S, Arribas JR, Arrizabalaga J, Baraia J, Casado JL, Cosín J, Polo R, González-García J, Iribarren JA, Kindelán JM, López-Bernaldo de Quirós JC, López-Vélez R, Lorenzo JF, Lozano F, Mallolas J, Miró JM, Pulido F, Ribera E: Prevención de las infecciones oportunistas en pacientes adultos y adolescentes infectados por el VIH. Recomendaciones de GESIDA/Plan Nacional sobre el Sida [Prevention of opportunistic infections in adult and adolescent patients with HIV infection. GESIDA/National AIDS Plan recommendations]. Enferm Infecc Microbiol Clin 2004, 22:160-176.

14. Ministerio de Sanidad y Consumo. Fondo de Investigación Sanitaria: Consenso nacional para el control de la tuberculosis [National consensus on the control of tuberculosis in Spain]. Med Clin (Barc) 1992, 98:24-31.

15. Hosmer DW, Lemeshow S: Applied Logistic Regression New York: WileyInterscience, 22000.

16. McCullagh P, Nelder J: Generalized Linear Models London: Chapman and Hall, 21989

17. Narita M, Kellman M, Franchini DL, McMillan ME, Hollender ES, Ashkin D: Short-course rifamycin and pyrazinamide treatment for latent tuberculosis infection in patients with HIV infection. The 2-year experience of a comprehensive community-based program in Broward County, Florida. Chest 2002, 122:1292-1298.

18. Martínez Alfaro EM, Cuadra F, Solera J, Maciá MA, Geijo P, Sánchez Martínez PA, Rodríguez Zapata M, Largo J, Sepúlveda MA, Rosa C, Sánchez L, Espinosa A, Mateos F, Blanch JJ: Evaluación de dos pautas de quimioprofilaxis tuberculosa en pacientes infectados por el virus de la inmunodeficiencia humana [Evaluation of 2 tuberculosis chemoprophylaxis regimens in patients infected with human immunodeficiency virus]. Med Clin (Barc) 2000, 115:161-165.

19. Rivero A, López-Cortés L, Castillo R, Verdejo J, García MA, MartínezMarcos FJ, Díez F, Escribano JC, Canueto J, Lozano F, Pasquau J, Hernández JJ, Márquez M, Kindelán JM, Grupo Andaluz para el estudio de las Enfermedades Infecciosas (GAEI): Ensayo clínico aleatorizado para evaluar tres pautas cortas de tratamiento de la infección latente tuberculosa en pacientes infectados por el VIH [Randomized clinical trial investigating three chemoprophylaxis regimens for latent tuberculosis infection in HIV-infected patients]. Enferm Infecc Microbiol Clin 2007, 25:305-310.

20. Pina-Gutiérrez JM, Ferrer-Traid A, Arias C, Sala-Farré MR, López-Sanmartín JL: Cumplimiento y efectividad del tratamiento de la infección tuberculosa con isoniazida durante 9 meses en una cohorte de 755 pacientes [Adherence and effectiveness of the treatment of latent tuberculosis infection with isoniazid for 9 months in a cohort of 755 patients]. Med Clin (Barc) 2008, 130:165-171.

21. Sackoff JE, Torian LV, Frieden TR, Brudney KF, Menzies IB: Purified protein derivative testing and tuberculosis preventive therapy for HIV-infected patients in New York City. AIDS 1998, 12:2017-2023.

22. Shieh FK, Snyder G, Horsburgh CR, Bernardo J, Murphy C, Saukkonen JJ: Predicting non-completion of treatment for latent tuberculous infection: a prospective survey. Am J Respir Crit Care Med 2006, 174:717-721.

23. García de Olalla P, Knobel H, Carmona A, Guelar A, López-Colomés JL, Caylà JA: Impact of adherence and highly active antiretroviral therapy on survival in HIV-infected patients. J Acquir Immune Defic Syndr 2002, 30:105-110.

24. Gourevitch MN, Hartel D, Selwyn PA, Schoenbaum EE, Klein RS: Effectiveness of isoniazid chemoprophylaxis for HIV-infected drug users at high risk for active tuberculosis. AIDS 1999, 13:2069-2074.
25. Portilla J, Jordá P, Esteban J, Sánchez-Payá J, Merino E, Boix V, Grupo de Estudio Protocolo-INH: Tratamiento directamente observado de la infección tuberculosa latente: estudio comparativo de dos pautas con isoniacida [Directly observed treatment of latent tuberculosis infection: comparative study of two isoniazid regimens]. Enferm Infecc Microbiol Clin 2003, 21:293-295.

26. Halsey NA, Coberly JS, Desormeaux J, Losikoff P, Atkinson J, Moulton LH, Contave M, Johnson M, Davis H, Geiter L, Johnson E, Huebner R, Boulos R, Chaisson RE: Randomised trial of isoniazid versus rifampicin and pyrazinamide for prevention of tuberculosis in HIV-1 infection. Lancet 1998, 351:786-792.

27. Mwinga A, Hosp M, Godfrey-Faussett P, Quigley M, Mwaba P, Mugala BN, Nyirenda O, Luo N, Pobee J, Elliott AM, McAdam KP, Porter JD: Twice weekly tuberculosis preventive therapy in HIV infection in Zambia. AIDS 1998, 12:2447-2457.

28. Gordin F, Chaisson RE, Matts JP, Miller C, de Lourdes Garcia M, Hafner R, Valdespino JL, Coberly J, Schechter M, Klukowicz AJ, Barry MA, O'Brien RJ: Rifampin and pyrazinamide vs isoniazid for prevention of tuberculosis in HIV-infected persons: an international randomized trial. Terry Beirn Community Programs for Clinical Research on AIDS, the Adult AIDS Clinical Trials Group, the Pan American Health Organization, and the Centers for Disease Control and Prevention Study Group. JAMA 2000, 283:1445-1450.

29. Centers for Disease Control and Prevention (CDC); American Thoracic Society: Update: adverse event data and revised American Thoracic Society/CDC recommendations against the use of rifampin and pyrazinamide for treatment of latent tuberculosis infection-United States, 2003. MMWR Morb Mortal Wkly Rep 2003, 52:735-739.

30. Sterling TR, Bethel J, Goldberg S, Weinfurter P, Yun L, Horsburgh CR, Tuberculosis Epidemiologic Studies Cosortium: The scope and impact of treatment of latent tuberculosis infection in the United States and Canada. Am J Respir Crit Care Med 2006, 173:927-931.

\section{Pre-publication history}

The pre-publication history for this paper can be accessed here: http://www.biomedcentral.com/1471-2334/10/267/prepub

\section{doi:10.1186/1471-2334-10-267}

Cite this article as: Diaz et al.: Eligibility for and outcome of treatment of latent tuberculosis infection in a cohort of HIV-infected people in Spain. BMC Infectious Diseases 2010 10:267.

\section{Submit your next manuscript to BioMed Central and take full advantage of:}

- Convenient online submission

- Thorough peer review

- No space constraints or color figure charges

- Immediate publication on acceptance

- Inclusion in PubMed, CAS, Scopus and Google Scholar

- Research which is freely available for redistribution

Submit your manuscript at www.biomedcentral.com/submit
C Biomed Central 